\title{
Addressing Sustainability within Public Procurement of Food: A Systematic Literature Review
}

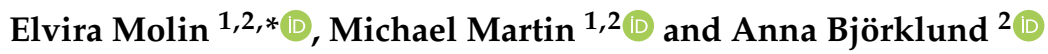 \\ 1 IVL Swedish Environmental Research Institute, Life Cycle Management, Sustainable Society, \\ 11428 Stockholm, Sweden; michael.martin@ivl.se \\ 2 Department of Sustainable Development, Environmental Science and Engineering, KTH Royal Institute of \\ Technology, 11428 Stockholm, Sweden; anna.bjorklund@abe.kth.se \\ * Correspondence: elvira.molin@ivl.se
}

\section{check for}

updates

Citation: Molin, E.; Martin, M.; Björklund, A. Addressing

Sustainability within Public

Procurement of Food: A Systematic

Literature Review. Sustainability 2021,

13, 13395. https://doi.org/10.3390/ su132313395

Academic Editors: Danny Hunter,

Luana F. Joppert Swensson,

Florence Tartanac, Sergio Schneider and Mark Stein

Received: 14 October 2021

Accepted: 26 November 2021

Published: 3 December 2021

Publisher's Note: MDPI stays neutral with regard to jurisdictional claims in published maps and institutional affiliations.

Copyright: (c) 2021 by the authors. Licensee MDPI, Basel, Switzerland. This article is an open access article distributed under the terms and conditions of the Creative Commons Attribution (CC BY) license (https:// creativecommons.org/licenses/by/ $4.0 /)$.

\begin{abstract}
Public procurement has been recognized as a tool to promote more sustainable production and consumption practices. As such, an increasing body of literature has become available in recent years focusing on the sustainable public procurement of food. This article reviews the literature on the sustainable public procurement of food with the aim to analyze how sustainability is framed. This is done by analyzing what aspects of sustainability are emphasized and what practices are identified as sustainable. A systematic literature review was conducted between the years 2000 and 2020, identifying 103 articles. Results from the literature review indicate that the focus has primarily been on studies to evaluate and explore policy and good practices for procuring sustainable foods. A dominant focus on specific foods types and origins, e.g., those locally sourced and organic foods, is highlighted by a large share of the literature to address all three sustainability pillars. We observed that most articles focus on all three pillars of sustainability (environmental, social, and economic), addressing different aspects and types of foods, although the focus varied depending upon geographic location. Despite many studies identifying opportunities and potential, few articles assess the sustainability or outcomes of procurement processes through quantitative or qualitative methods or how actors in the procurement process can improve procurement toward more sustainable foods. This indicates a need for further case studies and guidelines to measure the development, progress, and performance of public food procurement.
\end{abstract}

Keywords: public procurement; food; sustainable; policy; purchase; organic; local; green public procurement (GPP); sustainable public procurement (SPP)

\section{Introduction}

Activities related to the production and consumption of food are among the most significant contributors to climate change, accounting for 20-30\% of anthropogenic greenhouse gas (GHG) emissions [1-3]. These impacts occur throughout the entire life cycle of food, from production to consumption and the handling of food waste [3]. With an increasing population, the environmental impacts of food production and consumption will also continue to grow, despite efficiency gains [4].

While the pressing need for a sustainable food system is widely acknowledged, there is currently no consensus on how to transform it. Many articles outline different policy interventions to influence the sustainability of the food system, aimed at improving technologies, economic viability, and behavioral changes [5-7]. Public procurement can be defined as the procurement of goods, services or constructions on behalf of a public authority to meet certain criteria or requirements [8]. Public procurement has been highlighted in a number of studies as an effective approach to motivate more sustainable production methods. As such, the increased demand for sustainable products and services through public purchasing is thought to orient production and consumption in a more sustainable 
direction [9-12]. As public procurement can amount to roughly $20-30 \%$ of the gross domestic product [11,13-15], there is a significant potential to influence more sustainable production and consumption of food [16].

Different approaches for considering sustainability in public procurement have been developed, such as Green Public Procurement (GPP) and Sustainable Public Procurement (SPP). While GPP mainly focuses on environmental impacts, SPP aims to include environmental, social, health, and socio-economic aspects in the procurement [17]. Few articles have identified how sustainability is addressed in public procurement of food, despite previous literature reviews of food-related public procurement [18-20]. Salient information on how and what sustainability aspects are addressed and motivated with respect to food is essential to develop public procurement and build consensus [16,21-24].

This article aims to review and analyze how sustainability is framed in the scientific literature on public procurement of food-i.e., what aspects of sustainability are emphasized and what practices are identified as sustainable. Through a systematic literature review, this study investigates what aspects are the main focuses when addressing the three pillars of sustainability (environmental, social, and economic), and how these are discussed and motivated in the literature.

\section{Methodology}

To explore how sustainability is framed in the context of public procurement of food and food services in the scientific literature, a systematic literature review was conducted. The approach was employed due to its applicability to find articles of relevance and encompassing a broad range of disciplines. It allows the application of exclusion criteria to explore a range of scientific literature from different disciplines [25]. Similar methods have been applied to explore the research field of sustainable procurement, organic food in public kitchens, and environmental impacts in specific sectors [26-29].

The first step included identifying relevant peer-reviewed scientific literature between the years 2000 and 2020. The Scopus (www.scopus.com), GreenFile (www.gebsco.com) and Web of Science (www.webofknowledge.com) databases were employed for the searches, between 17 June 2019 and 18 December 2020, as they are established search engines and ensure coverage of a large number of publishers and journals across disciplines.

The development of the search string was done iteratively to avoid limiting the results yet avoiding articles off-topic. The search string was divided into four blocks, including terms identifying public, procurement, sustainability, and food. Furthermore, the search was limited to journal articles written in English. For terms which could include different variations of words, an "*' symbol was used. For example, the term 'sustainab*' was used to highlight variants of words such as sustainable, sustainability, etc. The final search string employed was as follows:

(TITLE-ABS-KEY (public OR government OR "public sector") AND TITLE-ABS-KEY (procurement OR tendering OR contracting OR purchasing) AND TITLE-ABS-KEY (sustainab*) AND TITLE-ABS-KEY (food OR catering OR grocer* OR eatables OR feeding*)) AND DOCTYPE (ar) AND PUBYEAR > 1999 AND (LIMIT-TO (LANGUAGE, "English"))

From the different search engines, a total of 368 articles were obtained. Upon reviewing the references in the collected articles, an additional 23 articles were added to the search upon reviewing the cited studies in the collected literature, giving a total of 391 articles. After removing duplicates, only 290 articles remained, where 19 articles were not accessible through the databases or provided on request and thus excluded. Thereafter, 271 articles were reviewed based on titles, keywords, and abstracts. Only articles specifically addressing public procurement of food and sustainability were selected, whereby articles covering private consumption and shopping as well as articles not addressing sustainability were excluded. In total, 103 articles remained for a more thorough review and analysis; see an overview of this process in Figure 1. 


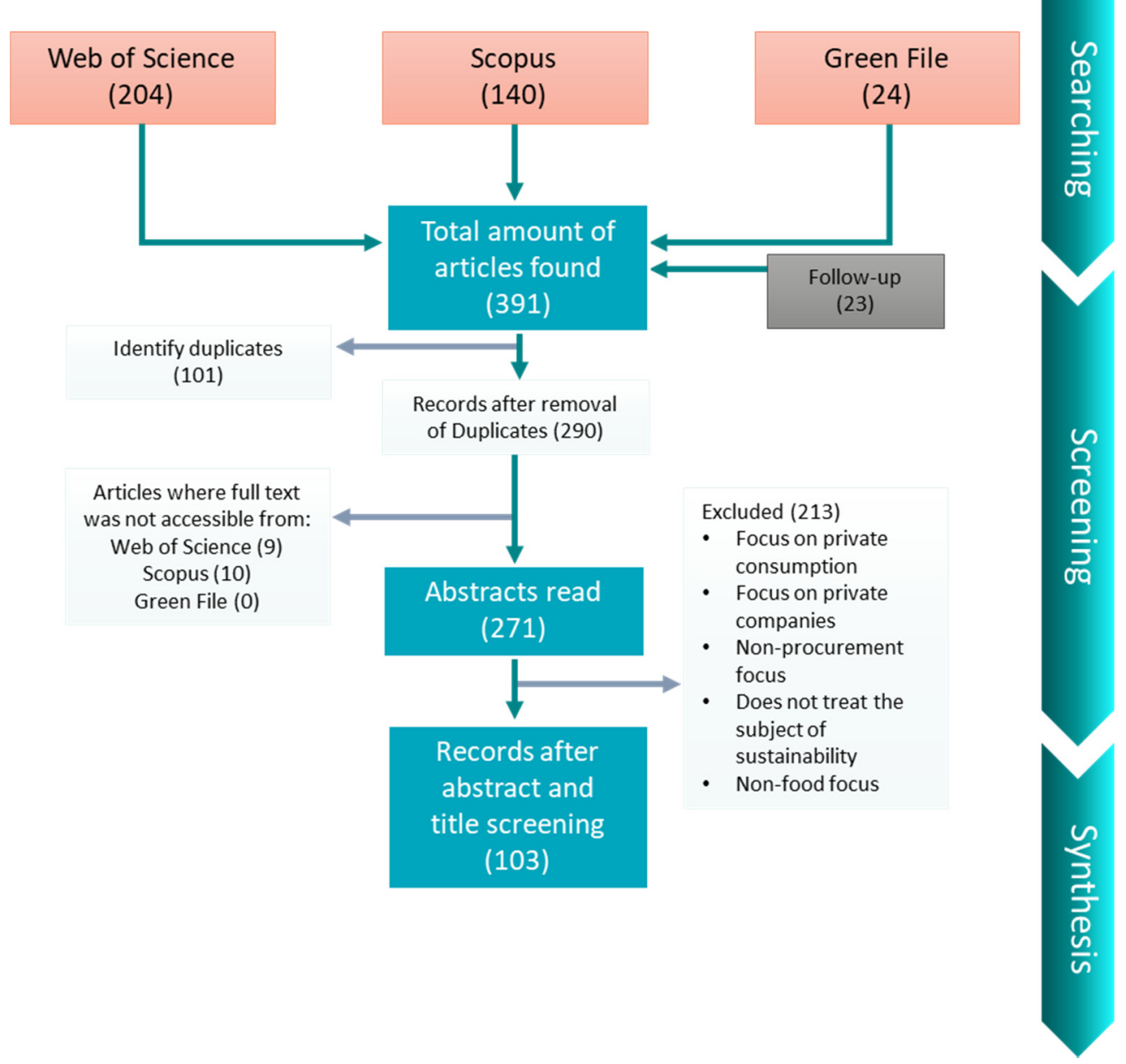

Figure 1. Depiction of the methodology for the systematic literature review.

Once the scientific articles were selected, content analysis was performed as the first step of interpreting findings from the collected literature. Content analysis is an efficient approach to search for and analyze phenomena that cannot be observed directly, including themes, words, and concepts within texts to understand their presence, relationships, and meaning $[30,31]$. In this article, we used content analysis to understand how sustainable food procurement is framed in the scientific literature. It included a descriptive content analysis to outline (1) the objectives of the studies, (2) what objects (e.g., specific food products, packaging, or technology) were studied, (3) what methods were used for study design and data collection, (4) geographical coverage, and (5) identifying focus words employed in the context of sustainability, e.g., local, organic and waste. This gave a general overview and understanding of sustainable food procurement literature and served as a background for further analysis. The content analysis also involved screening the articles to identify focus words, i.e., words used to address different sustainability aspects of food production and procurement. The occurrence of focus words was then analyzed. This excluded words which appeared as a combination of letters within another word or in the reference lists for the reviewed article.

From the content analysis outlined above, relational analysis was employed to further analyze how sustainability was framed. This was done by first categorizing how the focus words were used to address sustainability in the articles. This included environmental, social, economic sustainability, or a combination of the three, and cross-checking the occurrence of focus words for each article; see similar approaches developed in previous articles such as [32,33]. Thereafter, upon review of the selected articles, information was gathered regarding, e.g., salient sustainability aspects for public food procurement and in 
what context they were presented. The number of occurrences of each separate word was counted, as was the number of individual papers where they were mentioned; see Figure 2.

\section{Data collection}
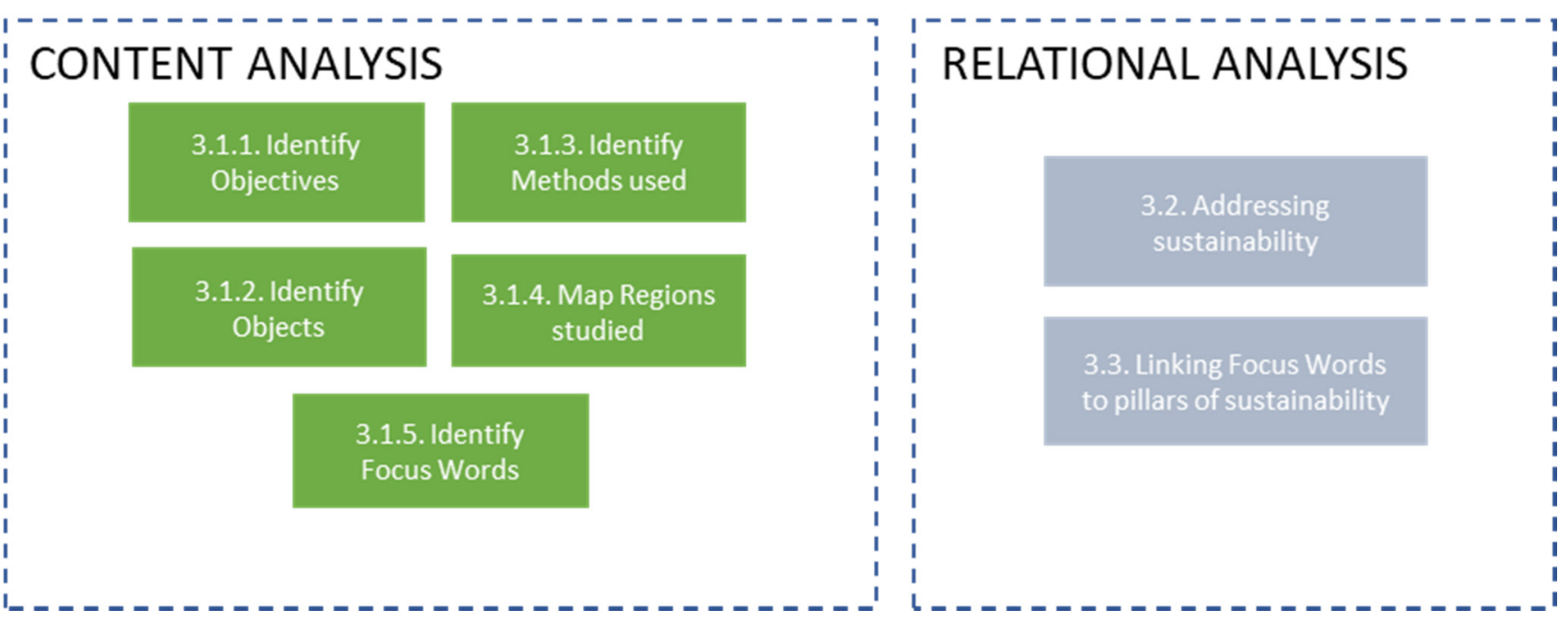

Figure 2. Depiction of the methodology and found focus areas employed for the content and relational analyses.

\section{Results}

The following sections provide the results of the content and relational analysis of the reviewed studies and how they frame sustainability.

\subsection{Content Analysis}

The content analysis includes a descriptive content analysis of the reviewed literature, which below includes a review of the objectives of the articles, objects studies, the types of studies, geographical regions studied, and the salient focus words in the articles.

\subsubsection{Objectives of the Articles}

Upon reviewing the articles, a number of themes emerged related to the objectives of the studies, see Figure 3. The most common objective among the reviewed articles, identified in 30 of the articles, was the 'evaluation of an implemented policy' aiming to improve food procurement. Examples of such policies include the Farm to School program [34,35], the Balanced Menu Challenge in Maryland [36], and the Food for Life Partnership program in the UK [37].

'Exploring different policy options' was the second most frequently occurring objective, which was identified in 26 of the articles. Examples of these included policies to support local food in public catering [38], increasing the shares of organic foods [39], and examining opportunities to promote small and medium-sized enterprises (SME) through public procurement $[28,40]$. 'Exploring good practice', i.e., reviewing previously successful or perceived beneficial examples of sustainable procurement, was the objective of five articles. These include using public procurement for human well-being and meeting environmental objectives [41], in addition to more specific practices for improving nutritional standards [42]. Other types of objectives included, e.g., 'practical examples' of how municipalities procure food [43,44], 'how to write public procurement documents' [43,45], and the 'development of procurement criteria' [44]. 


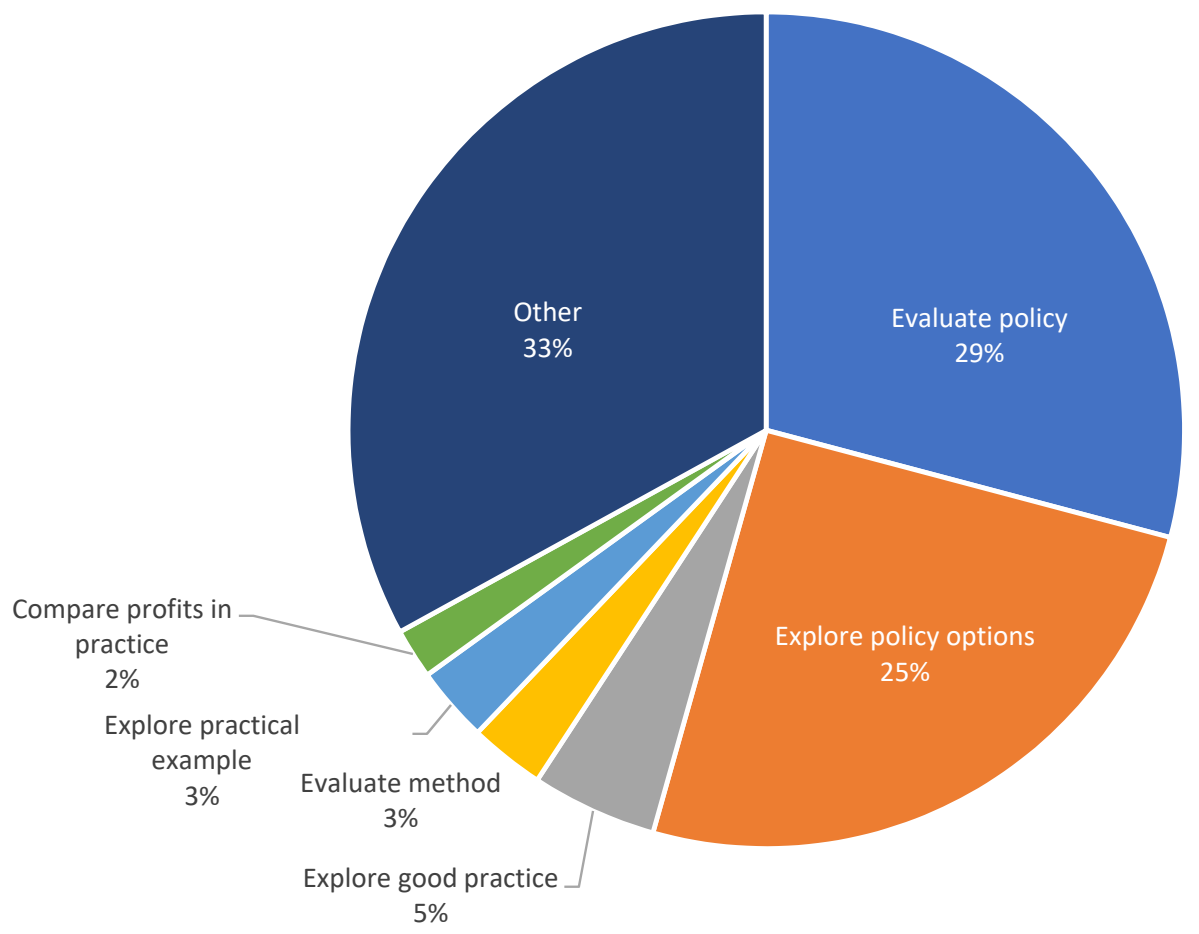

Figure 3. Illustration of the different objectives identified in the articles.

\subsubsection{Objects Studied}

The objects studied among the reviewed articles range from food procurement in general to studies of more specific food products, see Figure 4 . These identified objects were included as they appeared or were defined specifically in the articles. For example, 'beverages' is reported as a separate object and specifically identified in several studies, although beverages could be accounted for as 'food products.'

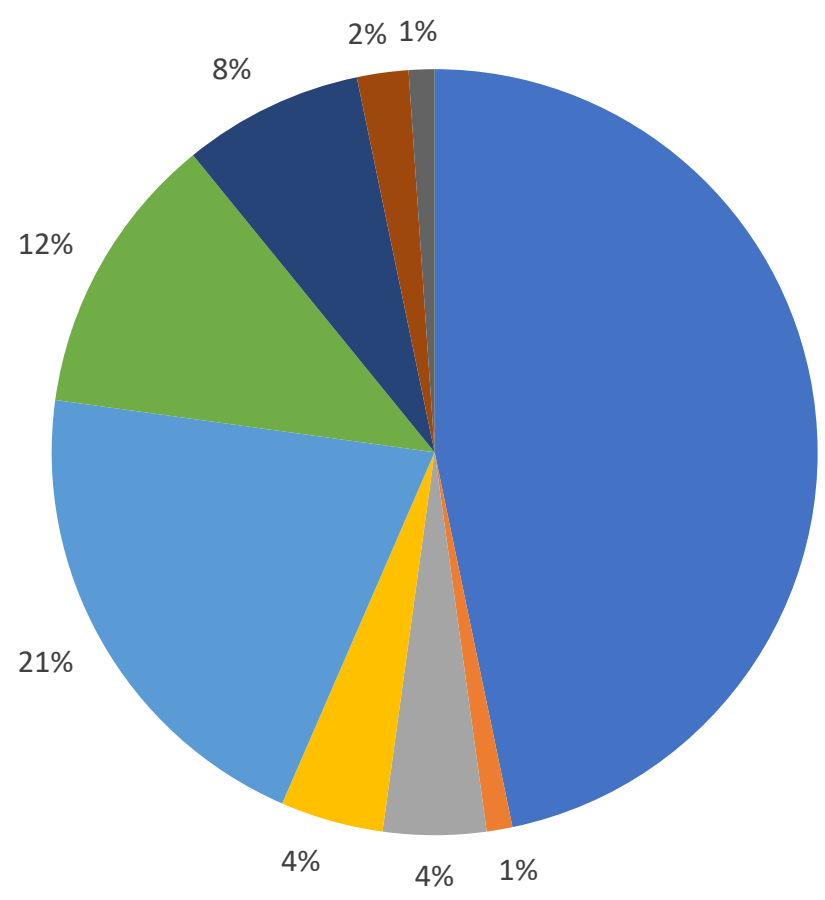

- Food services

Beverages

animal products

Crops

Food products

- Organic foods

- Local initiatives

- Packaging

- Agricultural technology

Figure 4. Illustration of the objects identified in the literature. 
'Food services', or meal services, were the most studied objects in the reviewed articles. These include food services (breakfast, lunch, dinner, and snacks) to schools, universities, hospitals, and elderly homes. 'Food products' were the second most common category, which included studies on unspecified, or aggregated compilations, of products, e.g., discussions on linkages between consumption and the environment [46], enhancing food security through public purchasing [47], and comparisons of power relations in the food system [48]. Studies explicitly relating to 'organic foods' and 'local' initiatives were also frequently studied [49]. Other objects studied in the reviewed articles included crops, animal products, packaging, beverages, and agricultural technology. Despite the fact that specific objects were found in the study, in the subsequent section on focus words, specific food types, production methods, and attributes are also highlighted which are those connected to sustainability aspects.

\subsubsection{Type of Studies Reviewed}

The reviewed articles were categorized into different types of studies based on the methods applied to assess and explore public procurement of food, see Figure 5.

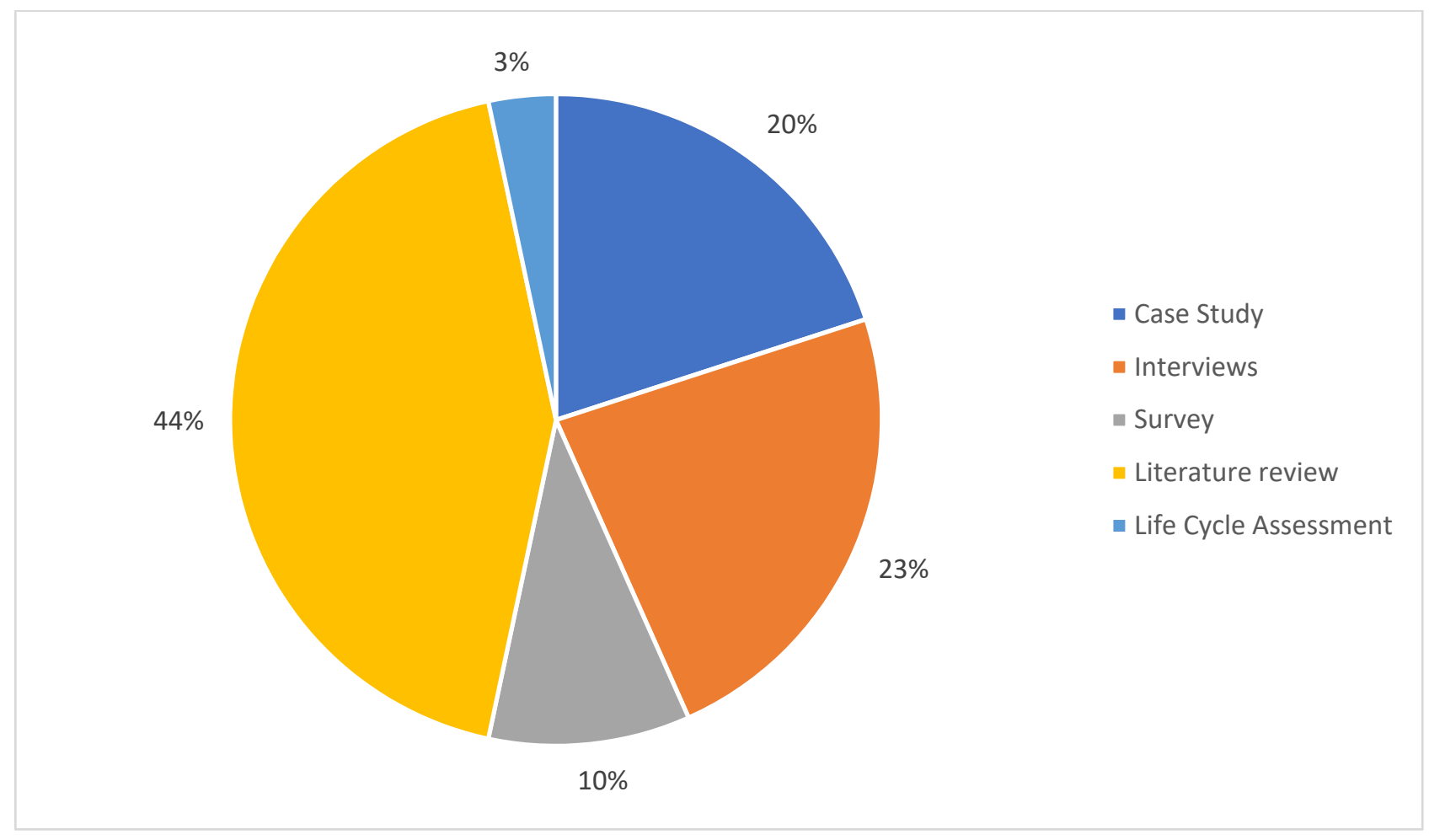

Figure 5. Illustration of the distribution of different methods used in the articles reviewed.

Case studies relating to specific examples of how procurement could be used in a particular setting or reviewing the outcomes of such procurement processes were common, occurring in roughly 22 articles. For example, these include identifying the causes of backof-house food waste and the potential for procurement to reduce wastes [45], investigating strategies for sustainable supply chains [20,50], or evaluating the efficiency of GPP [51]. Interviews were used to explore policy options and evaluate implemented policies among stakeholders. An example of such was investigating barriers in the school farming system in Brazil, see e.g., [52]. Surveys were also conducted to explore and evaluate policies. Furthermore, life cycle assessments were also employed in five articles, primarily to assess the environmental performance of meals or specific products $[53,54]$. Some of the articles also used mixed-method approaches, combining several of the aforementioned methods. An example includes the development of a tool to assess sustainability, which was created 
by both interviewing experts and an iterative process of data collection to identify key aspects in promoting more sustainable public procurement of food [55].

\subsubsection{Geographical Regions Studied}

Figure 6 provides a review of the geographical regions highlighted in the reviewed literature. The results suggest that roughly half of the literature focuses on European countries, with studies originating from the UK and Italy most prevalent. Of the 103 articles reviewed, 57 articles focused on European countries, where 4 cover the entire European Union. A total of 19 articles are from the UK, primarily focusing on policies and strategies for improving procurement. The literature from Italy focuses on former popular school food programs such as the project 'Procurement of Eco-Innovation in the Catering Sector' (INNOCAT) [19].

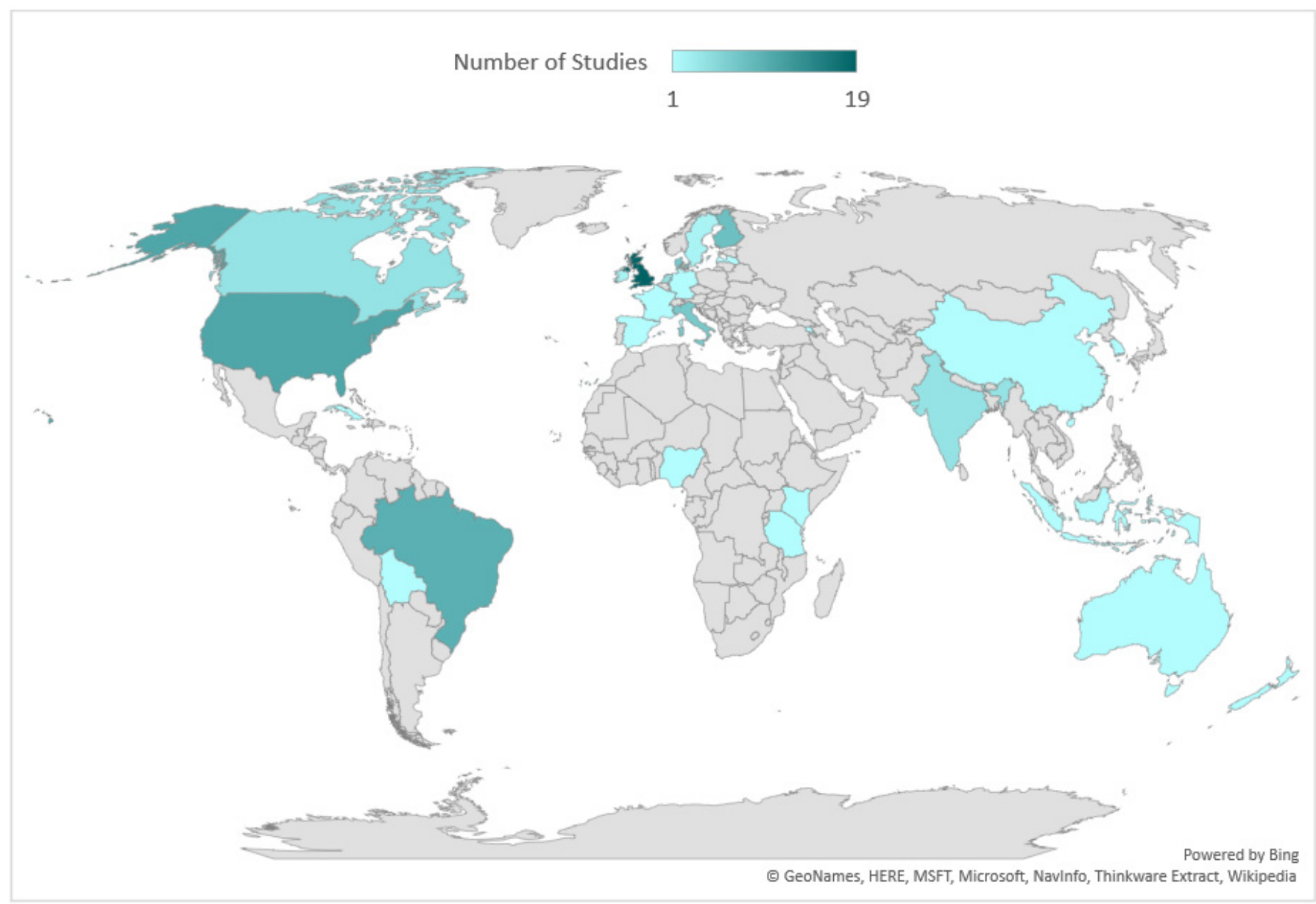

Figure 6. Geographical depiction of studied regions in articles.

European articles were found to have a strong environmental focus. Social issues, such as inclusion and safe and nutritious food for better health, are found more prominent in literature from North America and South America. North America is represented in 16 articles related to farm-to-school programs, food security, waste, and balancing menus, mainly for improved health and social sustainability. South America is represented in 11 articles, dominated by articles from Brazil, focusing primarily on ensuring that procurement identifies school meals and smallholder farmers' livelihood see, e.g., [52,56,57].

\subsubsection{Focus Words}

Focus words, i.e., words that are used in different ways to define or discuss the sustainability of food procurement, were identified through a manual screening of the 
literature. To further assess and categorize these, the number of occurrences in the articles was compiled, see Figure 7.

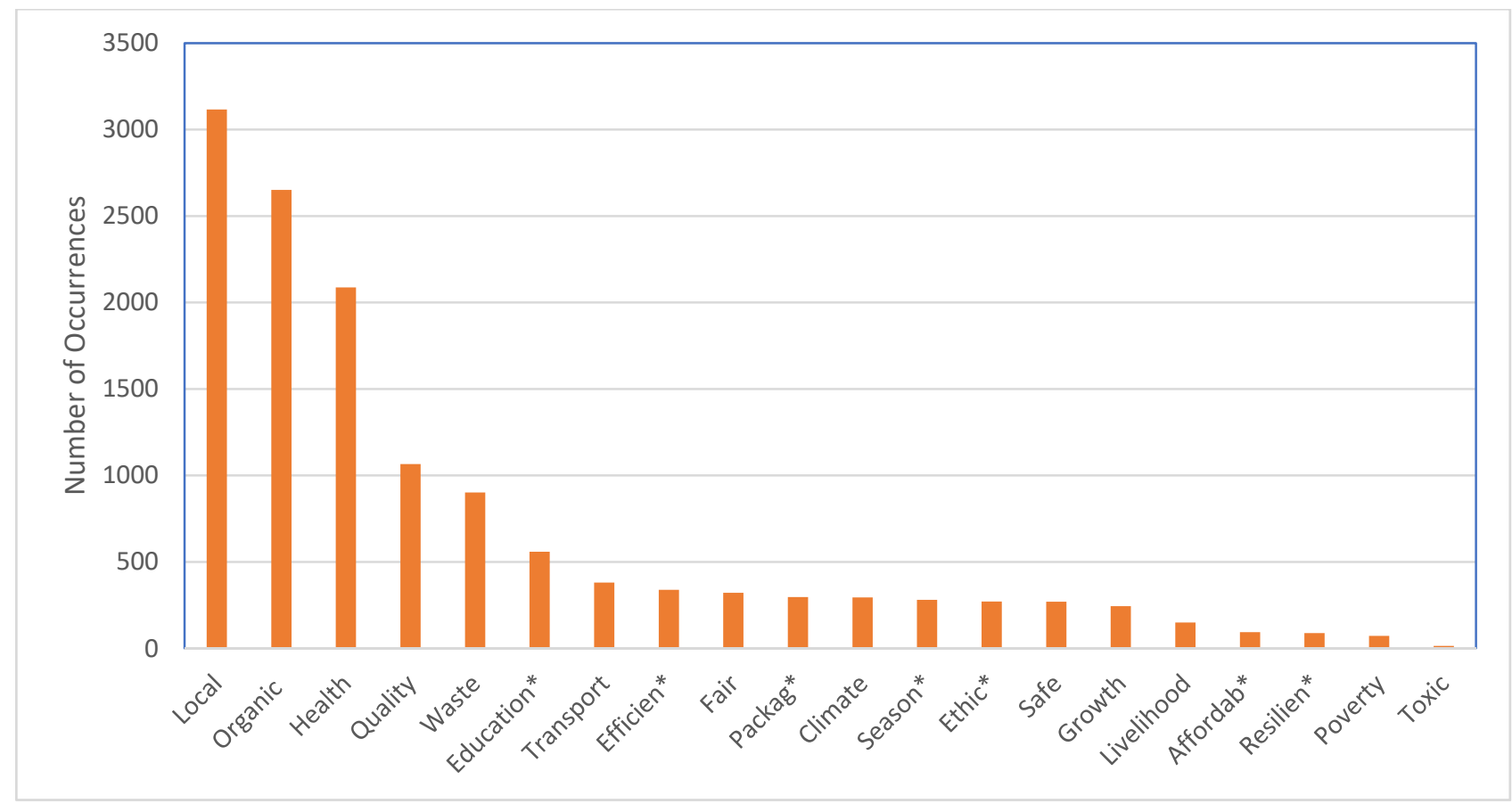

Figure 7. Occurrence of focus words in the reviewed articles. (The star next to some of the words refers to a cut of where different variations of that word are possible, e.g., efficien* can include efficient, efficiency etc.).

The emphasis of the focus words differs depending on the context in which they are used, which is further examined in subsequent sections through a relational analysis. The most prominent focus words were 'local', which appeared in the reviewed literature more than 3000 times (in 93 individual articles), 'organic' (mentioned over 2500 times in 72 articles), 'health' (mentioned over 2000 times in 89 articles), 'quality' (mentioned over 1000 times in 90 articles), 'waste' (mentioned roughly 1000 times in 29 articles), and 'education' (mentioned 559 times in 79 articles); see Figure 7. Other frequently occurring focus words to describe issues of sustainability included 'packaging', 'climate', 'resilience', 'fair', and 'ethical'.

\subsection{Relational Analysis}

\section{Addressing Sustainability}

To provide an analysis of how sustainability is framed in the literature on public procurement of food, the connection to the pillars was mapped. In total, 78 articles addressed aspects relating to economic sustainability, 95 articles of social sustainability aspects, and 89 addressing environmental sustainability of the public procurement of food. Several studies reviewed more than one pillar of sustainability. For example, a large number of studies, i.e., 62 articles were found to address all three pillars of sustainability, see Figure 8.

As illustrated in Table 1, while the different pillars may have been addressed in the articles, they may not have had a strong focus. As such, the articles were analyzed to understand whether the pillars of sustainability were strongly or weakly addressed. In this case, those studies that strongly addressed a pillar of sustainability were chosen to be those that specifically discussed or motivated a specific aspect and its link to sustainability. Studies found to have a weak link to a sustainability pillar may have been mentioned to address the specific pillar but had no argument or thorough motivation. 


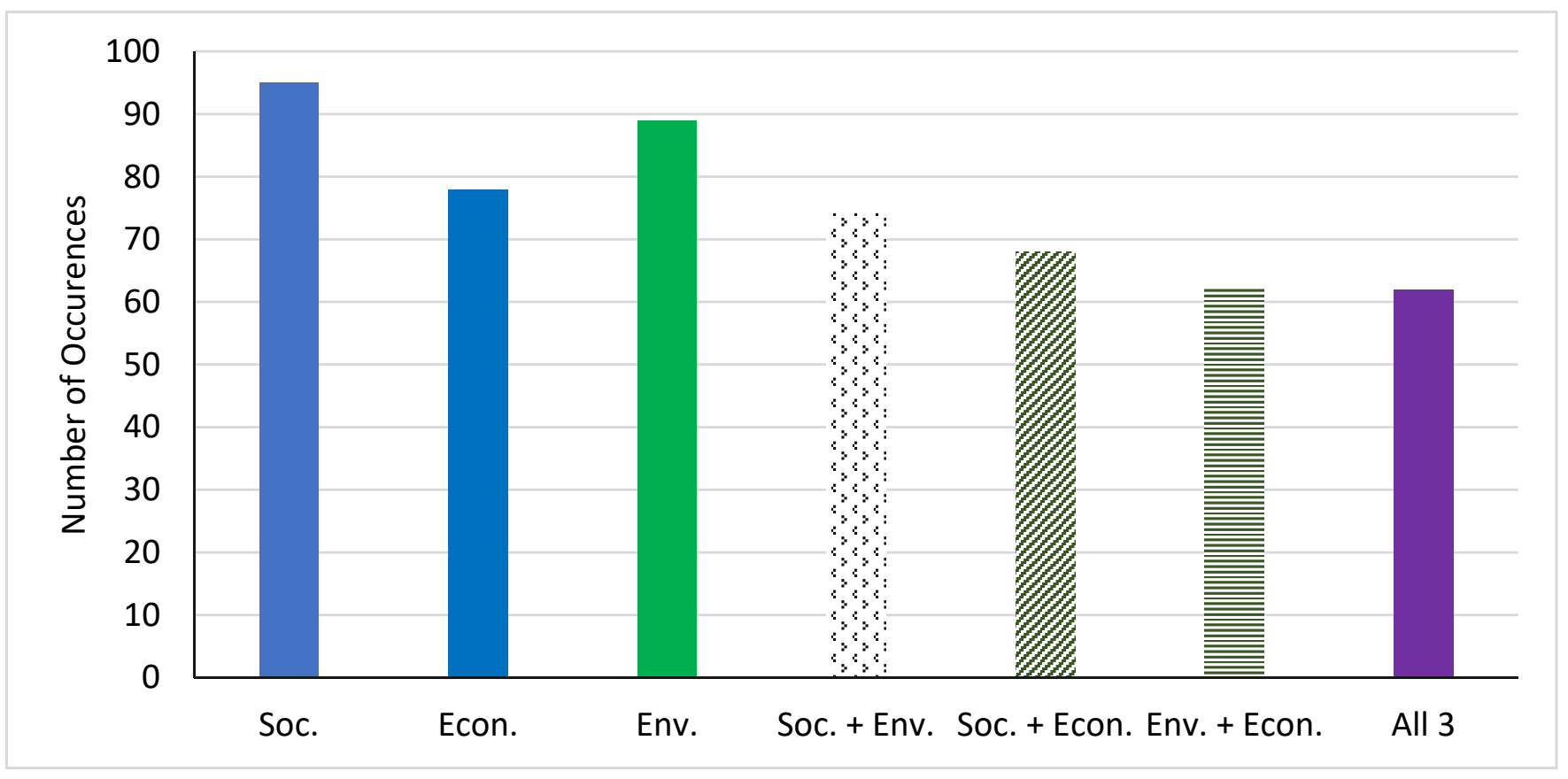

Figure 8. Number of articles reviewing the different pillars of sustainability (Social-Soc., Economic-Econ., Environmental-Env.).

Table 1. Articles addressing sustainability pillars.

\begin{tabular}{cccc}
\hline Link to Sustainability Pillar. & Social & Environmental & Economic \\
\hline Strong & 49 & 54 & 33 \\
Weak & 46 & 35 & 45 \\
Total & 95 & 89 & 78 \\
\hline
\end{tabular}

\subsection{Connecting Sustainability to Focus Words}

While Figure 8 illustrates the focus on different sustainability pillars in the articles, relational analysis was hereafter employed to analyze the contextual co-occurrence of the three pillars of sustainability employing the focus words. The following sections provide further elaboration on how different focus words were related to the environmental, economic and social pillars of sustainability.

\subsubsection{Framing Environmental Sustainability}

As illustrated in Figure 9, waste and organic foods were highlighted in relation to environmental sustainability. Waste, was primarily associated with waste due to meal preparation, menu design, or final consumer waste, see e.g., [50,58-60]. Different suggestions are brought forward in the articles to reduce food waste in the public sector, e.g., ensuring high quality ingredients are used, regulating staff capacity for food preparation, addressing the end consumer's needs, but also a need for policy measures to address the issue $[58,61]$. Reduced use of resources and reduced packaging was highlighted in several articles to relate to environmental sustainability, see e.g., [18,41,62]. A suggested measure to reduce waste was to employ a more 'systematic perspective' by increasing the share of recycled (and recyclable) materials for food packaging and redistribute food waste $[54,55,62,63]$. 


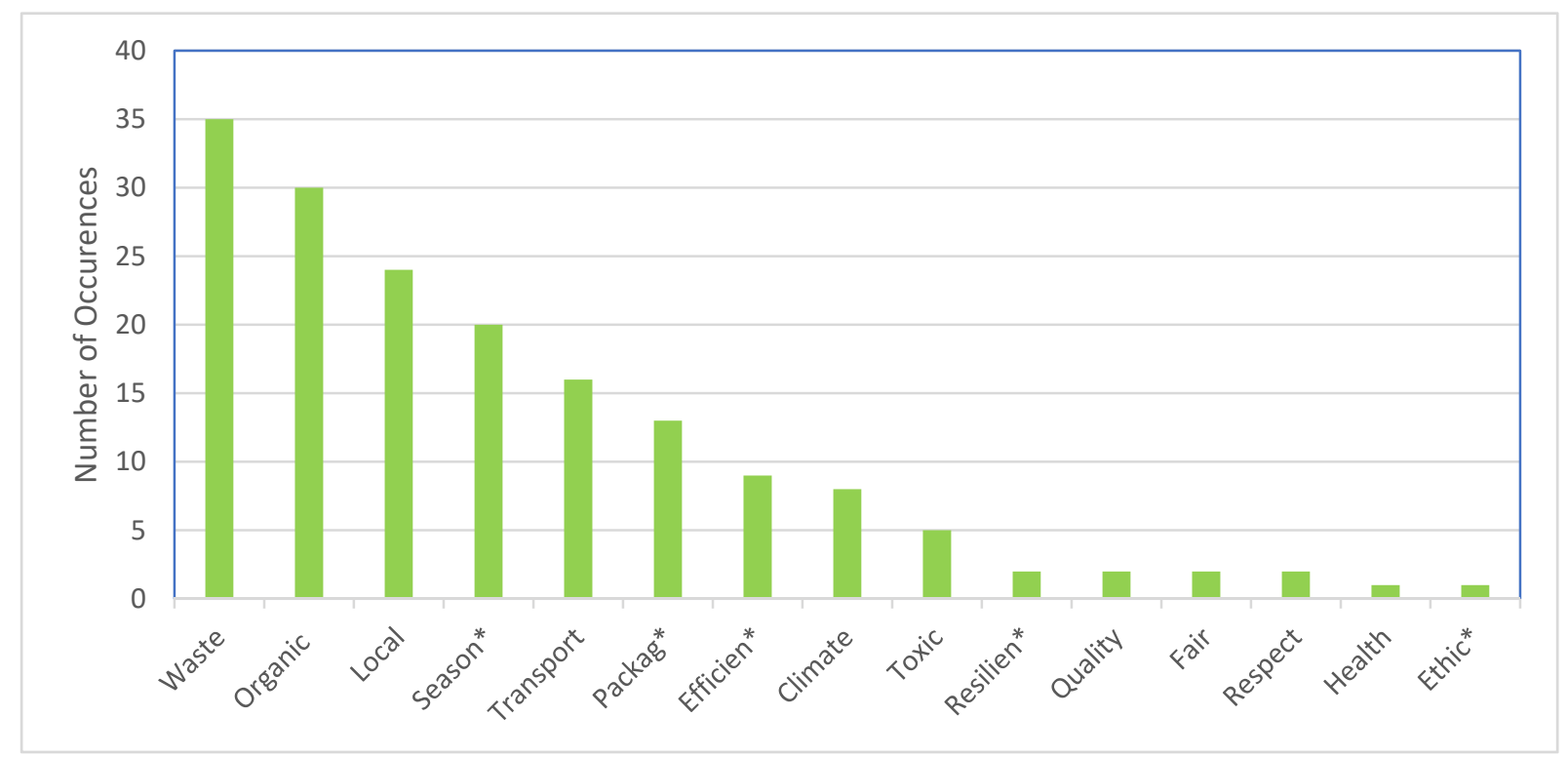

Figure 9. Focus words in the context of environmental sustainability. (The star next to some of the words refers to a cut of where different variations of that word are possible, e.g., efficien* can include efficient, efficiency etc.).

In the literature, it was generally assumed that organic foods are more environmentally sustainable than conventionally produced foods $[29,64,65]$. The procurement of organic food was primarily motivated by the reduced use of fertilizers and pesticides, preventing soil degradation and eutrophication, improved biodiversity, and reduced GHG emission $[19,39,46,53,55]$. It was found that organic labels were commonly used as a measure of environmentally sound products. This included different national forms of organic labeling schemes, such as the EU Ecolabel [66], and in Latin America, the IBD label, which was used in all six cases presented in Blanc and Kledal [56]. Finally, several articles claim that organic foods contain fewer chemicals, less antibiotics, and are more nutritious than conventional food products, thereby contributing to better health for consumers and the environment $[49,67,68]$.

From the results, local food was a prominent focus for articles addressing the environmental sustainability of public procurement of food. In a large number of articles, locally procured foods were mentioned as a way to reduce environmental impacts, by the reduced need for transportation, due to shorter distances for distribution (often referred to as 'food miles'). As such, many of the articles discussing reduced transportation, also were highlighting more local systems, even if it may not be explicit. In these articles, the minimized food miles, i.e., locally sourced food, were additionally assumed to contribute to a reduced need for packaging, due to close geographical proximity and reduced supply chain distances. The potential reduction of emissions from transportation when food is procured locally was frequently emphasized and mentioned in almost a third of the articles reviewed, see e.g., $[18,69,70]$. Food miles were also a common indicator highlighted to measure the sustainability of the public procurement of food $[58,62,70]$. Local foods were also identified to benefit the local environment. Procuring local food was claimed to be more ecologically beneficial on many levels, including diversifying agriculture and protecting local biodiversity by less intensive practices [38,55,57]. Local food producers were also suggested to be more energy-efficient due to a reduced need for storage and assumed to care more for the soil and water consumption than large conventional farmers [68]. As suggested in Valencia et al. [57], local food producers were considered contributors to national food system resilience and less affected by climate change due to their diversity.

While health was primarily identified as relating to social aspects of sustainability, it was also identified in several articles as relating to environmental sustainability. The most frequently identified approach to address human health within the procurement of food was by buying organic produce, which is assumed to additionally contribute to 
reduced environmental impacts [29,71]. Several articles claim that organic foods contain fewer chemicals, less antibiotics, and are more nutritious than conventional food products, thereby contributing to better health for consumers and the environment $[49,67,68]$. Others suggest that healthy diets are promoted through dietary initiatives in public procurements, e.g., through the reduction of the number of meat dishes served [18,62,72].

Climate change was addressed both in terms of practices to reduce environmental pressure, mainly by limiting GHG emissions. Several authors addressed adapting more climate-conscious agricultural strategies, see e.g., [19,55,73]. Furthermore, a large share of articles focused on reducing GHG emissions by minimizing food miles through procuring local foods, which was included in roughly one-third of the reviewed articles. In several of the articles, quantitative assessments and indicators were used to highlight environmental sustainability, which is primarily related to GHG emissions, and several articles employed life cycle assessment (LCA). 'Low carbon' procurements have also been investigated in other previous articles [69]. For example, Cerutti et al. [74] quantify the effectiveness of different procurement policies to reduce GHG emissions. Other studies also identify dietary changes as the most effective way to reduce environmental pressure, mainly by limited consumption of ruminant-based products [18]. Furthermore, several articles mentioned strategies to reduce meat consumption to mitigate climate change from food procurement $[18,29,36,55,67,74-77]$.

Seasonal foods, i.e., only purchasing products in season, were also considered environmentally sustainable in many of the articles $[40,55,62]$. This was motivated by the fact that seasonal food was considered 'fresh', having a reduced need for a chemical treatment that is otherwise required for a longer shelf-life [55]. Furthermore, a better understanding of production capacity and seasonality could help to balance supply and demand, additionally reducing waste in the production phase for improved environmental performance [78].

\subsubsection{Framing Social Sustainability}

As illustrated in Figure 10, health was often associated with social sustainability through nutritious food, resulting in improved well-being, see, e.g., [17,55]. Multiple authors highlight the importance of recognizing the contribution that nutritious and fresh foods have for good health and the prevention of food-related diseases, such as cardiovascular diseases, cancers, malnutrition, and obesity, see e.g., [35,79,80].

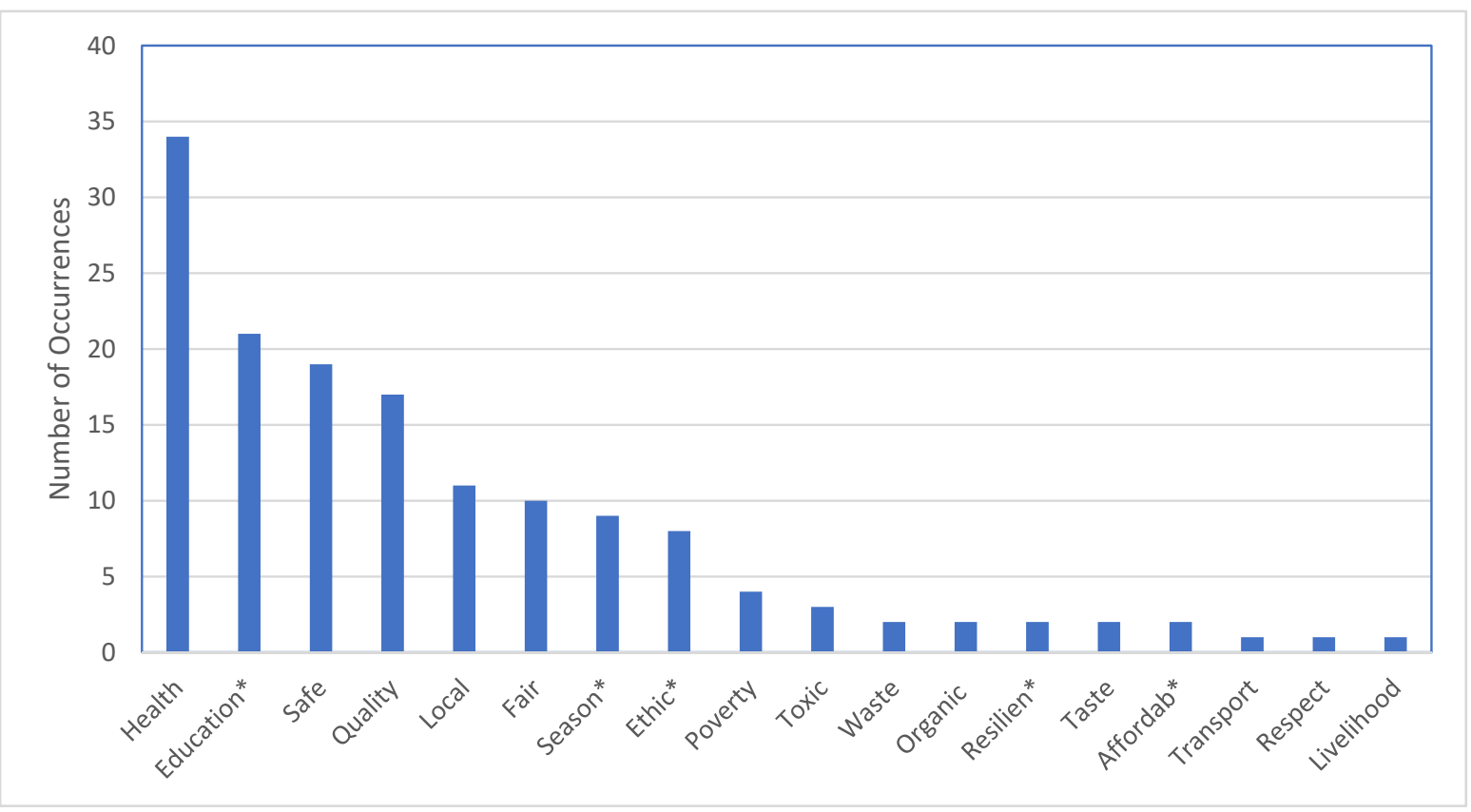

Figure 10. Focus words used in the context of social sustainability. (The star next to some of the words refers to a cut of where different variations of that word are possible, e.g., Ethic* can include ethical, ethically etc.). 
Education was identified in about half of the reviewed articles to relate to social sustainability. This was primarily related to programs and outcomes leading to the education of consumers (often school children), kitchen staff, as well as the procurement staff. Feeding school children was explored in several articles as an opportunity to impact eating habits towards nutritious, healthy, and sometimes local or organic food; e.g., the Brazilian School Feeding Program (PNAE) [81]. A handful of the articles discussed the opportunity that exists through schools and education to benefit local communities, see e.g., $[29,42,71,77,80,82,83]$.

Local food procurement was strongly linked to promoting social sustainability in the reviewed articles. Procuring local food was often associated with providing healthy and nutritious food, see e.g., [40,72,84]. Local food was also regarded as an assurance of quality and transparency, leading to consumers' trust and food security, see, e.g., [39,58,67,82,85,86]. Some of the reviewed articles mention that food can be an expression of culture and identity connected to geographical areas $[19,55,76,87]$. Therefore, sourcing local foods was suggested to contribute to the culture, education, and history, see e.g., [29,72].

Quality aspects of social sustainability were associated with safe food, which was primarily suggested to be fulfilled by transparency in the supply chain; once again also related to procuring local food as mentioned above, see e.g., $[39,58,67,82,85,86]$. Several studies also suggested that the involvement of parents of school children in the public procurement of food could increase the quality of the food being served through dialogue, see e.g., $[48,61,88]$. As such, several studies suggest that there is potential with demands on quality to create new food narratives and connect farmers to consumers, see e.g., $[46,58,61]$, creating more transparency and understanding of food systems.

Ethical concerns were also commonly highlighted in the reviewed literature. Neto and Caldas [89] suggest that criteria should be included in public procurement of food to ensure ethical aspects are taken into account, such as animal welfare, food safety, and fairly traded food products. Ethical issues relating to animal welfare were mentioned in several articles [18,76]. Adhering to fair trade labels was also suggested to promote ethical consumption and socially sustainable practices [56,90]. Fair Trade labels were mainly recognized as defending social issues of workers' rights, but it was also suggested to act as a guarantee for fair pricing and contribute to reduced poverty, see e.g., [55,76,91].

Other commonly identified words included safe and organic to promote social sustainability. Safe working conditions were discussed in several articles, see e.g., [61,90,92] and for staff in the kitchen and the local farmers [38,80]. Organic products were also suggested to contribute to social sustainability. This was motivated by their proposed contribution to the well-being of people through offering healthy, safe, and ethical choices.

\subsubsection{Framing Economic Sustainability}

As illustrated in Figure 11, locally procured food was identified as the most prominent focus for studies on economic sustainability. Rimmington, et al. [92] argue that local, regional, as well as the national economy could be supported by increasing purchases of local produce. Several of the reviewed articles suggest that supporting local farmers would benefit local economies. As such, ensuring that local farmers, and local SMEs are included in public purchasing is proposed to stimulate the market, increase job opportunities, and ensure steady income locally, see e.g., $[44,62,93]$. This was also suggested to reduce inequalities in the rural communities and help preserve local cultural values while also contributing to equity, see e.g., [55,86,94,95]. Nonetheless, Walker and Preuss [28] state that more stable, larger suppliers may be preferred due to risks. This was also highlighted as important in Brazilian food procurement programs, which take a systemic approach to transform agriculture and simultaneously benefit stakeholders along the supply chain [96]; once again also discussed to provide benefits such as the well-being and health of the local population, especially in deprived areas [28]. 


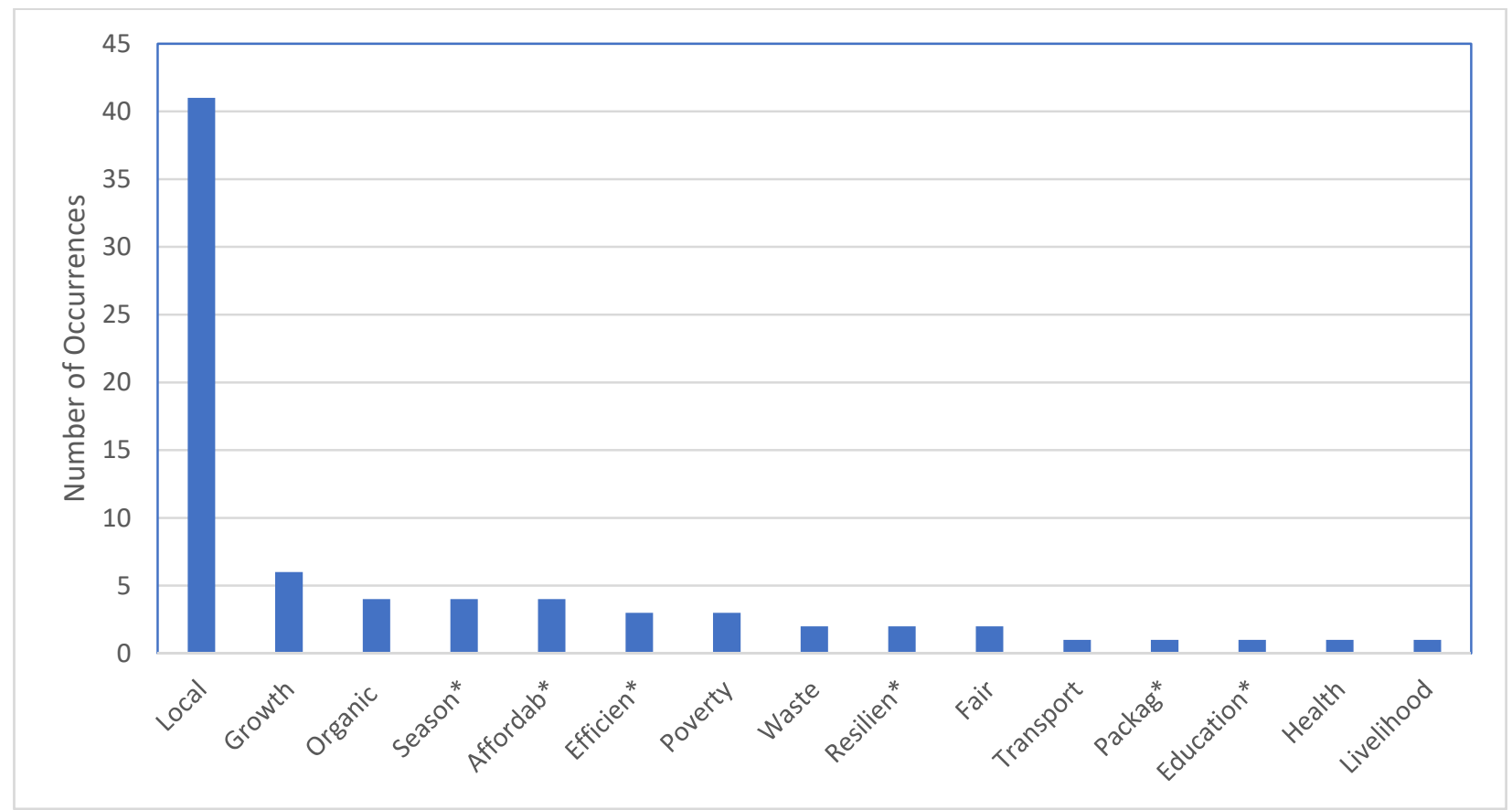

Figure 11. Focus words figuring in the context of economic sustainability. (The star next to some of the words refers to a cut of where different variations of that word are possible, e.g., season* can include seasons, seasonally etc.).

Growth was identified as a reoccurring word for economic sustainability in the reviewed literature. However, the context in which it is used was often related to the power relations between procuring authorities and stakeholders in the supply chain. As such, it was often associated with the growth of small producers and SMEs by using public procurement as a policy instrument to support more sustainable agricultural practices.

A number of articles investigate the economic impacts of solely procuring organic food. These studies investigate the technical challenges of how to increase the use of organic products and how to ensure their economic viability by reducing purchase prices, see e.g., $[49,86,93,97,98]$. Several articles found that small farmers turn to organic farming as an option to increase income, see e.g., $[38,56,61,72,99,100]$.

Reducing waste was identified as a contributor to reduced environmental pressure as previously mentioned, but was also associated with cost savings [29,101]. As mentioned in Sonnino and McWilliam [58], the economic capacity of, e.g., kitchen staff, can have a large influence on the amount of waste. Furthermore, taking actions to valorize waste was also identified to contribute to economic sustainability, see, e.g., [18,74].

The use of the focus word 'livelihood' was used primarily to describe economic sustainability. According to the reviewed literature, livelihood could be determined by costs and the ability to pay, the use of subsidies, governmental support, and support from NGOs $[100,102]$. Other important economic aspects related to livelihood included employment rates, reduction of poverty, the possibility to be self-sufficient (regarding supplies of seeds) [52,92]. Márcia Pozzagnol et al. [52] claim that a sustainable livelihood in rural areas for farmers is accomplished by ensuring that they receive the resources needed to make a living, including income and fair pricing on their products. The problem with fluctuating prices could be addressed with demands for price guarantees for goods secured through public procurement $[103,104]$.

Other prominent focus words, including health, seasonal, and quality, were also associated with economic sustainability. Health, in the context of economic sustainability, was associated with reduced costs for health care due to better health, see e.g., [17,18,52,55,105]. The most frequent way to address better human health through food was, as mentioned above, to procure organic products. It was suggested that cost savings for the procurer could be achieved, not only by cheaper products but through procuring a larger share of 
seasonal food and better menu planning $[29,101]$. Finally, quality was highlighted in a number of articles to reduce costs through the reduction of waste and cost efficiency in buying quality products $[55,58]$.

\section{Discussion}

The results of this article identify a large divergence in the depth at which they addressed sustainability in the public procurement of food. The following sections discuss these findings, highlighting how the literature addresses sustainability, the focus on certain aspects and types of foods, the geographical differences, and the potential for public procurement to promote sustainable consumption and production of food.

\subsection{Addressing Sustainability in Food Procurement}

The results suggest that all three sustainability pillars were accounted for in the reviewed literature. These were often related to common focus words, but also potential environmental implications and perceived benefits. In the articles, environmental and social sustainability were the most salient. Similar results were identified in Stefani et al. [27], where social aspects and environmental sustainability through green public procurement were found to be common themes.

Environmental sustainability was found to be addressed by discussing the benefits of certain types of foods, e.g., organic and local foods (see also discussions below) and their perceived sustainable outcomes. Such findings were broadly represented in the text, and associated with, e.g., reduced climate change, damage to ecosystems, less pollution and pesticides (e.g., toxicity), and reduced resource consumption and waste. This broad and complex view of the environmental sustainability implications was an interesting finding, as studies on sustainable consumption of food are generally limited in their scope, often addressing only climate change, see, e.g., discussions in [106,107]. Social sustainability was primarily addressed by discussing the implications of food choices. This included suggestions that procuring food should ensure that issues such as fair trade, fair wages, safe working conditions, ethical purchasing, and healthy diets for consumers are addressed. Similar findings have also been found in previous studies addressing social sustainability in food systems $[22,43,108]$. Additionally, economic sustainability was focused primarily on economic viability and livelihoods, primarily for national and local producers.

Despite the narrative provided in the articles that suggest a number of positive implications for the sustainability of food systems through public procurement, few articles assess the sustainability or outcomes of procurement processes through quantitative or qualitative methods. As outlined, most articles are accounts of past procurement processes or discussions on future potential, with only a few applied methods linked to indicators on the implications for sustainability through life cycle assessment or other methods. In several articles, environmental sustainability was proxied by referring to the potential GHG emission reductions of particular foods or assumed benefits from certain types of foods, e.g., local and organic. Similar findings are also discussed in Goggins and Rau [52], where GHG emissions (and reductions thereof) are assumed to represent sustainability broadly. While addressing environmental sustainability, other major social and economic aspects were not covered. Similar findings have been highlighted for bioenergy systems, due in part to the science-policy framework used to promote bioenergy, see [24].

\subsection{Highlighting Certain Food Types and Labels}

The literature review highlights aspects and types of foods that were used to address sustainability. A large number of focus words were found to be linked to sustainable procurement. However, as previously mentioned, procuring organic and local foods, in addition to reducing wastes, were promoted in most studies as an approach to ensure sustainable consumption and production of foods. Similar findings are also emphasized in a number of articles analyzing different national programs for sustainable food procurement [82,109-112]. 
In many of the reviewed studies, procuring local food is assumed to be environmentally beneficial due to reduced transportation or reduced food miles. Notwithstanding, as stipulated by previous studies, the use of food miles to account for environmental sustainability may not be a good proxy for sustainability, although it continues to be represented in the discourse on food sustainability [113-115] and is often used in public procurement of food as important aspect $[38,116]$. However, the procurement from local producers was also perceived as a risk in the supply chain for some procuring authorities and partners, where a preference toward more established companies was preferred to ensure the economic viability of the procurement, see, e.g., [28].

Organic foods were also promoted to address all three pillars of sustainability, although the motivations primarily focused on the environmental sustainability related to reduced environmental impacts. Several studies also suggest organic foods to reduce GHG emissions, although there are conflicting views of this in the literature $[106,117]$. Organic foods were often promoted as healthier choices, which also concurs with the narrative used to promote these foods in the consumer sphere $[109,110]$. Nonetheless, as Rigby et al. [118] suggest, sustainability in the food system is more about transitioning towards more sustainable practices, and organic foods can help to address this change but are not sustainable by default.

Finally, despite an abundance of literature on transforming the food system through more sustainable food choices [24,119-121], few studies addressed certain types of foods to procure. For example, only a few of the reviewed articles suggest a reduction of meat as an approach to improve the sustainability of food produced and consumed through public procurement [18].

\subsection{Geographical Scope}

From the reviewed articles, some notable geographical differences were outlined. Literature from the European Union, North America, and South America are most salient in the literature on sustainable public procurement of food. Similar findings were also highlighted in a recent review [27].

The focus of the studies, with regards to sustainability, was also divergent. Articles focusing on Europe focused primarily on environmental sustainability. This may be explained by the fact that in recent years, environmental impacts of consumption have seen an increased focus in the EU, with, e.g., footprinting and labelling being promoted as an approach to guide public procurement toward more environmental sustainability [122,123]. Nonetheless, in Europe, North and South America, studies addressing economic and social sustainability are also prevalent. Wahlen et al. [112] suggest that such findings can be motivated by the increased political pressure to use public procurement to promote national economies.

\subsection{Improving Sustainable Public Procurement of Food}

There is an ongoing debate about the role of public institutions and procurement as a tool to achieve sustainability objectives $[13,61,124]$. Although several articles mention the difficulties of public procurement, there seems to be a lack of studies addressing how to improve the procurement processes. Furthermore, the development of food procurement entails changes to how public meals are handled and structured. Few articles highlight the implications of this, and more knowledge on its effects for planning, kitchen staff, and stakeholders involved in the food supply chain are needed. For example, few studies have outlined how criteria can steer procurement beyond addressing local and organic foods. Similar assertions are also highlighted in [27]. Additionally, future research could be directed towards gathering more examples of best practices and finding weak links in the procurement process in order to promote more sustainable public procurement of food. As such, further studies exploring how public procurement can be improved are needed.

A number of studies have also addressed the potential to disrupt the conventional practice of employing 'costs' to guide procurement [82]. Inclusion of a life cycle perspec- 
tive, i.e., taking into account aspects along the life cycle of different food products from production to consumption and waste handling, could highlight the implications of current procurement practices and motivate higher demands for sustainable products rather than the price [125]. The Swedish national policy also suggests that a life cycle perspective should be employed in procurement. Nevertheless, few studies provide empirical evidence on the implications of different procurement strategies towards promoting more sustainable food production and consumption. This calls for further studies on the potential positive and negative effects of sustainable public procurement.

\section{Conclusions}

This article aimed to analyze the framing of sustainability in the scientific literature on sustainable public food procurement. The results indicate that there is a variance in the extent to which the three pillars of sustainability and the focus on specific types of foods, production methods, and attributes are addressed. Above all, we found that the literature strongly emphasizes procuring locally sourced and organic foods, which is suggested to positively address all three pillars of sustainability. Furthermore, environmental sustainability was identified primarily with procurement which reduced waste and sourced organic, seasonal, and local foods. Social sustainability was found to primarily be associated with healthy foods, the promotion of fair-trade foods, safe working conditions, and related to the educational aspects of food. Finally, economic sustainability was related principally to promoting economic viability and livelihoods, primarily for national and local producers. The focus on the three pillars of sustainability also varied depending upon geographic location, with studies from North and South America tending to focus on social and economic sustainability, while European studies focused primarily on environmental sustainability. The studies are also primarily related to exploring policies and good practices for procuring sustainable foods, although few articles assess the sustainability or outcomes of procurement processes through quantitative or qualitative methods, in addition to how actors in the procurement process can improve procurement. This indicates a further need for case studies and guidelines to measure the development, progress, and performance of public food procurements.

One major limitation of this study is the focus on scientific literature. This is due to the fact that the scientific literature may not fully capture the work that is being done by different actors to promote sustainable public procurement of food. Therefore, the results could be further enhanced by additional grey literature or by interviews with practitioners, which may provide a richer empirical base.

This review sheds light on the possible direction that the public food sector is taking for achieving sustainability through public procurement. While sustainability is acknowledged to be widely addressed, we conclude that it is important to ensure that sustainability is considered in broader terms beyond procuring local and organic foods. Additionally, further studies are needed to understand the implications of procurement decisions for food to ensure they meet their intended outcomes. Knowledge from this study can be used to help guide future research on sustainable public procurement of food, criteria development for foods, and provide insights to inform processes to improve sustainability along the procurement supply chain, which is important for ensuring the viability and effectiveness of sustainable procurement.

Author Contributions: Conceptualization, M.M., E.M. and A.B.; methodology, E.M., M.M. and A.B.; formal analysis, E.M., M.M. and A.B.; investigation, E.M.; data curation, E.M.; writing-original draft preparation, E.M., M.M. and A.B.; writing—review and editing, E.M. and M.M.; visualization, E.M. and M.M.; supervision, M.M. and A.B.; project administration, M.M. and A.B.; funding acquisition, M.M. and A.B. All authors have read and agreed to the published version of the manuscript.

Funding: This research was funded by the Swedish Research Council for Sustainable Development, grant number 2017-00563.

Institutional Review Board Statement: Not applicable. 
Informed Consent Statement: Not applicable.

Data Availability Statement: Not applicable.

Acknowledgments: We would like to extend our gratitude to the anonymous reviewers who have carefully and thoroughly provided input which greatly helped to improve the transparency and clarity of the message.

Conflicts of Interest: The authors declare no conflict of interest. The funders had no role in the design of the study; in the collection, analyses, or interpretation of data; in the writing of the manuscript, or in the decision to publish the results.

\section{References}

1. Tukker, A.; Huppes, G.; Guinée, J.; Heijungs, R.; de Koning, A.; Oers, L.; Suh, S.; Geerken, T.; van Holderbeke, M.; Jansen, B.; et al. Environmental Impact of Products (EIPRO): Analysis of the Life Cycle Environmental Impacts Related to the Final Consumption of the EU-25; Leiden University Repository: Rapenburg, The Netherlands, 2006.

2. Martin, M.; Danielsson, L. Environmental Implications of Dynamic Policies on Food Consumption and Waste Handling in the European Union. Sustainability 2016, 8, 282. [CrossRef]

3. Gustavsson, J.; Cederberg, C.; Sonesson, U. Global Food Losses and Food Waste; Food and Agriculture Organization: Rome, Italy, 2011.

4. Foley, J.A.; Ramankutty, N.; Brauman, K.A.; Cassidy, E.S.; Gerber, J.S.; Johnston, M.; Mueller, N.D.; O'Connell, C.; Ray, D.K.; West, P.C.; et al. Solutions for a cultivated planet. Nature 2011, 478, 337-342. [CrossRef] [PubMed]

5. $\quad$ Ekvall, T.; Elander, M.; Umpfenbach, K.; Hirschnitz-Garbers, M.; Hudson, C.; Wunder, S.; Nesbit, M.; Keenleyside, C.; Mazza, L.; Russi, D.; et al. Development of DYNAMIX Policy Mixes; IVL Swedish Environmental Research Institute: Stockholm, Sweden, 2016; pp. 1-235.

6. Martin, M.; Ekvall, T.; Laurenti, R.; Danielsson, L.; Oliveira, F.; Palm, D. DYNAMIX: Deliverable 6. 1 Physical and Environmental Assessments of Dynamic Policy Mixes in the EU; IVL Swedish Environmental Research Institute: Stockholm, Sweden, 2016.

7. de Schutter, O. On Our Plate Today: Healthy, Sustainable Food Choices; LiveWell: Rome, Italy, 2015.

8. Konkurrensverket. The Public Procurement Act (2016:1145); Konkurrensverket Swedish Competition Authority: Stockholm, Sweden, 2016.

9. UNEP. Buying for a Better World-A Guide on Sustainable Procurement for the UN System; United Nations Environment Programme: Paris, France, 2014.

10. Ahi, P.; Searcy, C. A comparative literature analysis of definitions for green and sustainable supply chain management. J. Clean Prod. 2013, 52, 329-341. [CrossRef]

11. Testa, F.; Annunziata, E.; Iraldo, F.; Frey, M. Drawbacks and opportunities of green public procurement: An effective tool for sustainable production. J. Clean. Prod. 2016, 112, 1893-1900. [CrossRef]

12. Witjes, S.; Lozano, R. Towards a more Circular Economy: Proposing a framework linking sustainable public procurement and sustainable business models. Resour. Conserv. Recycl. 2016, 112, 37-44. [CrossRef]

13. Upphandlingsmyndigeten. Statistik om Offentlig Upphandling 2018; Konkurrensverket Swedish Competition Authority: Stockholm, Sweden, 2018.

14. Crippa, M.; Solazzo, E.; Guizzardi, D.; Monforti-Ferrario, F.; Tubiello, F.N.; Leip, A. Food systems are responsible for a third of global anthropogenic GHG emissions. Nat. Food 2021, 2, 1-12. [CrossRef]

15. Vermeir, I.; Weijters, B.; De Houwer, J.; Geuens, M.; Slabbinck, H.; Spruyt, A.; van Kerckhove, A.; van Lippevelde, W.; de Steur, H.; Verbeke, W. Environmentally Sustainable Food Consumption: A Review and Research Agenda from a Goal-Directed Perspective. Front. Psychol. 2020, 11, 1603. [CrossRef] [PubMed]

16. Morley, A. Procuring for change: An exploration of the innovation potential of sustainable food procurement. J. Clean. Prod. 2021, 279, 123410. [CrossRef]

17. Smith, J.; Andersson, G.; Gourlay, R.; Karner, S.; Mikkelsen, B.E.; Sonnino, R.; Barling, D. Balancing competing policy demands: The case of sustainable public sector food procurement. J. Clean. Prod. 2016, 112, 249-256. [CrossRef]

18. Reisch, L.; Eberle, U.; Lorek, S. Sustainable food consumption: An overview of contemporary issues and policies. Sustain. Sci. Pract. Policy 2013, 9, 7-25. [CrossRef]

19. Cerutti, A.K.; Contu, S.; Ardente, F.; Donno, D.; Beccaro, G.L. Carbon footprint in green public procurement: Policy evaluation from a case study in the food sector. Food Policy 2016, 58, 82-93. [CrossRef]

20. Brindley, C.; Oxborrow, L. Aligning the sustainable supply chain to green marketing needs: A case study. Ind. Mark. Manag. 2014, 43, 45-55. [CrossRef]

21. Klintman, M.; Boström, M. Political consumerism and the transition towards a more sustainable food regime: Looking behind and beyond the organic shelf. Food Practices in Transition; Routledge: London, UK, 2012.

22. Joosse, S.; Hracs, B.J. Curating the quest for 'good food': The practices, spatial dynamics and influence of food-related curation in Sweden. Geoforum 2015, 64, 205-216. [CrossRef] 
23. MacRae, R.; Szabo, M.; Anderson, K.; Louden, F.; Trillo, S. Empowering the Citizen-Consumer: Re-Regulating Consumer Information to Support the Transition to Sustainable and Health Promoting Food Systems in Canada. Sustainability 2012, 4, 2146-2175. [CrossRef]

24. Clark, M.; Tilman, D. Comparative analysis of environmental impacts of agricultural production systems, agricultural input efficiency, and food choice. Environ. Res. Lett. 2017, 12, 064016. [CrossRef]

25. Haddaway, N.R.; Pullin, A.S. The Policy Role of Systematic Reviews: Past, Present and Future. Springer Sci. Rev. 2014, 2, 179-183. [CrossRef]

26. Lazarevic, D.; Martin, M. Life cycle assessments, carbon footprints and carbon visions: Analysing environmental systems analyses of transportation biofuels in Sweden. J. Clean. Prod. 2016, 137, 249-257. [CrossRef]

27. Stefani, G.; Lombardi, G.V.; Tiberti, M. Public Food Procurement: A Systematic Literature Review. Int. J. Food Syst. Dyn. 2017, 8 , 270-283. [CrossRef]

28. Walker, H.; Preuss, L. Fostering sustainability through sourcing from small businesses: Public sector perspectives. J. Clean. Prod. 2008, 16, 1600-1609. [CrossRef]

29. Filippini, R.; De Noni, I.; Corsi, S.; Spigarolo, R.; Bocchi, S. Sustainable school food procurement: What factors do affect the introduction and the increase of organic food? Food Policy 2018, 76, 109-119. [CrossRef]

30. Krippendorff, K. Content Analysis an Introduction to Its Methodology; SAGE Publications: Tauzand Ouks, CA, USA, 2004; Volume 2, p. 422.

31. Kassarjian, H.H. Content Analysis in Consumer Research. J. Consum. Res. 1977, 4, 8. [CrossRef]

32. Rajesh, R.; Ravi, V. Supplier selection in resilient supply chains: A grey relational analysis approach. J. Clean. Prod. 2015, 86, 343-359. [CrossRef]

33. Martin, M.; Røyne, F.; Ekvall, T.; Moberg, Å. Life Cycle Sustainability Evaluations of Bio-based Value Chains: Reviewing the Indicators from A Swedish Perspective. Sustainability 2018, 10, 547. [CrossRef]

34. Thompson, O.M.; Twomey, M.P.; Hemphill, M.A.; Keene, K.; Seibert, N.; Harrison, D.J.; Stewart, K.B. Farm to School Program Participation: An Emerging Market for Small or Limited-Resource Farmers? J. Hunger. Environ. Nutr. 2014, 9, 33-47. [CrossRef]

35. Powell, L.J.; Wittman, H. Farm to school in British Columbia: Mobilizing food literacy for food sovereignty. Agric. Hum. Values 2018, 35, 193-206. [CrossRef]

36. Ranke, T.D.; Mitchell, C.L.; George, D.M.S.; D'Adamo, C.R. Evaluation of the Balanced Menus Challenge: A healthy food and sustainability programme in hospitals in Maryland. Public Health Nutr. 2015, 18, 2341-2349. [CrossRef]

37. Jones, M.; Dailami, N.; Weitkamp, E.; Salmon, D.; Kimberlee, R.; Morley, A.; Orme, J. Food sustainability education as a route to healthier eating: Evaluation of a multi-component school programme in English primary schools. Health Educ. Res. 2012, 27, 448-458. [CrossRef] [PubMed]

38. Lehtinen, U. Sustainability and local food procurement: A case study of Finnish public catering. Br. Food J. 2012, $114,1053-1071$. [CrossRef]

39. Løes, A.-K.; Nölting, B. Increasing organic consumption through school meals—Lessons learned in the iPOPY project. Org. Agric. 2011, 1, 91-110. [CrossRef]

40. Conner, D.; Nowak, A.; Berkenkamp, J.; Feenstra, G.; Kim, J.V.S.; Liquori, T.; Hamm, M. Value Chains for Sustainable Procurement in Large School Districts: Fostering Partnerships. J. Agric. Food Syst. Community Dev. 2011, 1, 55-68. [CrossRef]

41. Bloomfield, C. Putting sustainable development into practice: Hospital food procurement in Wales. Reg. Stud. Reg. Sci. 2015, 2, 552-558. [CrossRef]

42. Robles, B.; Wood, M.; Kimmons, J.; Kuo, T. Comparison of Nutrition Standards and Other Recommended Procurement Practices for Improving Institutional Food Offerings in Los Angeles County, 2010-2012. Adv. Nutr. 2013, 4, 191-202. [CrossRef]

43. Fairchild, R.M.; Morgan, M.Z. Delivering multidisciplinary public health in action-The Cardiff Food Strategy case study. Public Health Nutr. 2007, 10, 42-48. [CrossRef] [PubMed]

44. Braun, C.L.; Rombach, M.; Häring, A.M.; Bitsch, V. A Local Gap in Sustainable Food Procurement: Organic Vegetables in Berlin's School Meals. Sustainability 2018, 10, 4245. [CrossRef]

45. Maertens, M.; Velde, K.V. Contract-farming in Staple Food Chains: The Case of Rice in Benin. World Dev. 2017, 95, 73-87. [CrossRef]

46. Brunori, G.; Di Iacovo, F. Urban Food Security and Landscape Change: A Demand-side Approach. Landsc. Res. 2014, 39, 141-157. [CrossRef]

47. Endres, A.B.; Endres, R. The European Union, Agriculture, and the Tropics: Public Financial Incentives to Enhance Food Security and Expansion of Production Contracts. Trop. Conserv. Sci. 2017, 10, 1-4. [CrossRef]

48. Rossi, A.; Bui, S.; Marsden, T. Redefining power relations in agrifood systems. J. Rural. Stud. 2019, 68, 147-158. [CrossRef]

49. Risku-Norja, H.; Løes, A.-K. Organic food in food policy and in public catering: Lessons learned from Finland. Off. J. Int. Soc. Org. Agric. Res. 2016, 7, 111-124. [CrossRef]

50. Charlebois, S.; Creedy, A.; von Massow, M. "Back of house"—Focused study on food waste in fine dining: The case of Delish restaurants. Int. J. Cult. Tour. Hosp. Res. 2015, 9, 278-291. [CrossRef]

51. Lundberg, S.; Marklund, P.-O. Green public procurement and multiple environmental objectives. Econ. Polit. Ind. 2018, 45, 37-53. [CrossRef] 
52. Mossmann, M.P.; Teo, C.R.P.A.; Busato, M.A.; Triches, R.M. Interface Between Family Farming and School Feeding: Barriers and coping mechanisms from the perspective of different social actors in Southern Brazil. Rev. Econ. Sociol. Rural. 2017, 55, 325-342. [CrossRef]

53. De Laurentiis, V.; Hunt, D.V.L.; Lee, S.E.; Rogers, C.D.F. EATS: A life cycle-based decision support tool for local authorities and school caterers. Int. J. Life Cycle Assess. 2018, 24, 1222-1238. [CrossRef]

54. Saxe, H.; Okkels, S.L.; Jensen, J.D. How to Obtain Forty Percent Less Environmental Impact by Healthy, Protein-Optimized Snacks for Older Adults. Int. J. Environ. Res. Public Health 2017, 14, 1514. [CrossRef] [PubMed]

55. Goggins, G.; Rau, H. Beyond calorie counting: Assessing the sustainability of food provided for public consumption. J. Clean. Prod. 2016, 112, 257-266. [CrossRef]

56. Blanc, J.; Kledal, P.R. The Brazilian organic food sector: Prospects and constraints of facilitating the inclusion of smallholders. J. Rural. Stud. 2012, 28, 142-154. [CrossRef]

57. Valencia, V.; Wittman, H.; Blesh, J. Structuring Markets for Resilient Farming Systems. Agron. Sustain. Dev. 2019, 39, 25. [CrossRef]

58. Sonnino, R.; McWilliam, S. Food waste, catering practices and public procurement: A case study of hospital food systems in Wales. Food Policy 2011, 36, 823-829. [CrossRef]

59. Gaddis, J.; Coplen, A.K. Reorganizing School Lunch for a More Just and Sustainable Food System in the US. Fem. Econ. 2018, 24, 89-112. [CrossRef]

60. Sørensen, N.N.; Lassen, A.D.; Løje, H.; Tetens, I. The Danish Organic Action Plan 2020: Assessment method and baseline status of organic procurement in public kitchens. Public Health Nutr. 2015, 18, 2350-2357. [CrossRef]

61. Galli, F.; Brunori, G.; Di Iacovo, F.; Innocenti, S. Co-Producing Sustainability: Involving Parents and Civil Society in the Governance of School Meal Services. A Case Study from Pisa, Italy. Sustainability 2014, 6, 1643-1666. [CrossRef]

62. Doherty, S.; Cawood, J.; Dooris, M. Applying the whole-system settings approach to food within universities. Perspect. Public Health 2011, 131, 217-224. [CrossRef]

63. Correia, F.; Howard, M.; Hawkins, B.; Pye, A.; Lamming, R. Low carbon procurement: An emerging agenda. J. Purch. Supply Manag. 2013, 19, 58-64. [CrossRef]

64. Mørk, T.; Bech-Larsen, T.; Grunert, K.G.; Tsalis, G. Determinants of citizen acceptance of environmental policy regulating consumption in public settings: Organic food in public institutions. J. Clean. Prod. 2017, 148, 407-414. [CrossRef]

65. Kimmons, J.; Jones, S.; McPeak, H.H.; Bowden, B. Developing and Implementing Health and Sustainability Guidelines for Institutional Food Service. Adv. Nutr. 2012, 3, 337-342. [CrossRef]

66. European Commission. EU Ecolabel Products/Services Keep Growing. Available online: https://ec.europa.eu/environment/ ecolabel/facts-and-figures.html (accessed on 25 October 2021).

67. Sørensen, N.N.; Tetens, I.; Løje, H.; Lassen, A.D. The effectiveness of the Danish Organic Action Plan 2020 to increase the level of organic public procurement in Danish public kitchens. Public Health Nutr. 2016, 19, 3428-3435. [CrossRef] [PubMed]

68. Mikkola, M. Shaping professional identity for sustainability. Evidence in Finnish public catering. Appetite 2009, 53, 56-65. [CrossRef]

69. Caputo, P.; Clementi, M.; Ducoli, C.; Corsi, S.; Scudo, G. Food Chain Evaluator, a tool for analyzing the impacts and designing scenarios for the institutional catering in Lombardy (Italy). J. Clean. Prod. 2017, 140, 1014-1026. [CrossRef]

70. Pullman, M.; Wikoff, R. Institutional sustainable purchasing priorities: Stakeholder perceptions vs environmental reality. Int. J. Oper. Prod. Manag. 2017, 37, 162-181. [CrossRef]

71. Stahlbrand, L. The Food for Life Catering Mark: Implementing the Sustainability Transition in University Food Procurement. Agriculture 2016, 6, 46. [CrossRef]

72. Harvie, J.; Mikkelsen, L.; Shak, L. A New Health Care Prevention Agenda: Sustainable Food Procurement and Agricultural Policy. J. Hunger. Environ. Nutr. 2009, 4, 409-429. [CrossRef] [PubMed]

73. Wang, J.; Wang, Y.; Li, S.; Qin, D. Climate adaptation, institutional change, and sustainable livelihoods of herder communities in northern Tibet. Ecol. Soc. 2016, 21. [CrossRef]

74. Cerutti, A.K.; Ardente, F.; Contu, S.; Donno, D.; Beccaro, G.L. Modelling, assessing, and ranking public procurement options for a climate-friendly catering service. Int. J. Life Cycle Assess. 2018, 23, 95-115. [CrossRef]

75. He, C.; Mikkelsen, B.E. The association between organic school food policy and school food environment: Results from an observational study in Danish schools. Perspect. Public Health 2014, 134, 110-116. [CrossRef] [PubMed]

76. Kleine, D.; Brightwell, M.D.G. Repoliticising and scaling-up ethical consumption: Lessons from public procurement for school meals in Brazil. Geoforum 2015, 67, 135-147. [CrossRef]

77. Castner, E.; Leach, A.; Leary, N.; Baron, J.; Compton, J.E.; Galloway, J.N.; Hastings, M.G.; Kimiecik, J.; Lantz-Trissel, J.; De La Reguera, E.; et al. The Nitrogen Footprint Tool Network: A Multi-Institution Program to Reduce Nitrogen Pollution. Sustainability 2017, 10, 79-88. [CrossRef] [PubMed]

78. Wittman, H.; Blesh, J. Food Sovereignty andFome Zero: Connecting Public Food Procurement Programmes to Sustainable Rural Development in Brazil. J. Agrar. Chang. 2017, 17, 81-105. [CrossRef]

79. Tanksale, A.; Jha, J. Implementing National Food Security Act in India: Issues and challenges. Br. Food J. 2015, 117, 1315-1335. [CrossRef]

80. Nelson, M.; Breda, J. School food research: Building the evidence base for policy. Public Health Nutr. 2013, 16, 958-967. [CrossRef] 
81. Sidaner, E.; Balaban, D.; Burlandy, L. The Brazilian school feeding programme: An example of an integrated programme in support of food and nutrition security. Public Health Nutr. 2013, 16, 989-994. [CrossRef]

82. Morgan, K. Greening the Realm: Sustainable Food Chains and the Public Plate. Reg. Stud. 2008, 42, 1237-1250. [CrossRef]

83. Sonnino, R.; Torres, C.L.; Schneider, S. Reflexive governance for food security: The example of school feeding in Brazil. J. Rural. Stud. 2014, 36, 1-12. [CrossRef]

84. Sztam, K.A.; Ndirangu, M.; Sheriff, M.; Arpadi, S.M.; Hawken, M.; Rashid, J.; Deckelbaum, R.J.; El Sadr, W.M. Rationale and design of a study using a standardized locally procured macronutrient supplement as adjunctive therapy to HIV treatment in Kenya. AIDS Care 2013, 25, 1138-1144. [CrossRef] [PubMed]

85. Ruge, D.; Mikkelsen, B.E. Local public food strategies as a social innovation: Early insights from the LOMA-Nymarkskolen case study. Acta Agric. Scand. Sect. B Plant Soil Sci. 2013, 63, 56-65. [CrossRef]

86. Nuutila, J.; Risku-Norja, H.; Arolaakso, A. Public kitchen menu substitutions increase organic share and school meal sustainability at equal cost. Org. Agric. 2019, 9, 117-126. [CrossRef]

87. Schwartzman, F.; Mora, C.A.R.; Bogus, C.M.; Villar, B.S. Background and elements of the linkage between the brazilian school feeding program and family farming. Cad. Saude Publica 2017, 33, 1-2. [CrossRef]

88. Sonnino, R. Quality Food, Public Procurement, and Sustainable Development: The School Meal Revolution in Rome. Environ. Plan. A Econ. Space 2009, 41, 425-440. [CrossRef]

89. Neto, B.A.F.; Caldas, M.G. The use of green criteria in the public procurement of food products and catering services: A review of EU schemes. Environ. Dev. Sustain. 2018, 20, 1905-1933. [CrossRef]

90. Lo, J.; Delwiche, A. The Good Food Purchasing Policy: A Tool to Intertwine Worker Justice with a Sustainable Food System. J. Agric. Food Syst. Community Dev. 2016, 6, 185. [CrossRef]

91. Kolk, A. Towards a Sustainable Coffee Market: Paradoxes Faced by a Multinational Company. Corp. Soc. Responsib. Environ. Manag. 2012, 19, 79-89. [CrossRef]

92. Rimmington, M.; Smith, J.C.; Hawkins, R. Corporate social responsibility and sustainable food procurement. Br. Food J. 2006, 108, 824-837. [CrossRef]

93. Tikkanen, I. Procurement and consumption of local and organic food in the catering of a rural town. Br. Food J. 2014, 116, 419-430. [CrossRef]

94. Tolley, B.; Gregory, R.; Marten, G.G. Promoting resilience in a regional seafood system: New England and the Fish Locally Collaborative. J. Environ. Stud. Sci. 2015, 5, 593-607. [CrossRef]

95. Antier, C.; Kumar, S.; Bhagwat, S.; Sankar, R. Production of fortified food for a public supplementary nutrition program: Performance and viability of a decentralised production model for the Integrated Child Development Services Program, India. Asia Pac. J. Clin. Nutr. 2014, 23, S20-S28.

96. Guerra, J.; Blesh, J.; Schmitt, A.L.; Wittman, H. Pathways to agroecological management through mediated markets in Santa Catarina, Brazil. Elem. Sci. Anth. 2017, 5, 67. [CrossRef]

97. Mikkelsen, B.E.; Sylvest, J. Organic Foods on the Public Plate: Technical Challenge or Organizational Change? J. Foodserv. Bus. Res. 2012, 15, 64-83. [CrossRef]

98. Tikkanen, I. Steps towards an organic professional kitchen. Nutr. Food Sci. 2012, 42, 181-188. [CrossRef]

99. Thatcher, J.; Sharp, L. Measuring the local economic impact of National Health Service procurement in the UK: An evaluation of the Cornwall Food Programme and LM3. Local Environ. 2008, 13, 253-270. [CrossRef]

100. Seyfang, G. New Initiatives for Sustainable Food: A Case Study of an Organic Producer Cooperative; Working Paper; The Centre for Social and Economic Research on the Global Environment: Norwich, UK, 2004; pp. 1-24.

101. Goggins, G. Developing a sustainable food strategy for large organizations: The importance of context in shaping procurement and consumption practices. Bus. Strat. Environ. 2018, 27, 838-848. [CrossRef]

102. Wichelns, D. The Impact of Public Policies on the Sustainabilit of Rice and Wheat Producation on the Indo-Gangetic Plains. J. Sustain. Agric. 2004, 23, 67-92. [CrossRef]

103. Abraham, T.J.; Sil, S.; Vineetha, P. A comparative study of the aquaculture practices adopted by fish farmers in Andhra Pradesh and West Bengal. Indian J. Fish 2010, 57, 41-48.

104. Simangunsong, E.; Hendry, L.; Stevenson, M. Managing supply chain uncertainty with emerging ethical issues. Int. J. Oper. Prod. Manag. 2016, 36, 1272-1307. [CrossRef]

105. Coleman, P.; Gultig, J.; Emanuel, B.; Gee, M.; Orpana, H. Status report-FoodReach Toronto: Lowering food costs for social agencies and community groups. Health Promot. Chronic Dis. Prev. Can. 2018, 38, 23-28. [CrossRef]

106. Martin, M.; Brandão, M. Evaluating the Environmental Consequences of Swedish Food Consumption and Dietary Choices. Sustainability 2017, 9, 2227. [CrossRef]

107. Röös, E.; Sundberg, C.; Tidåker, P.; Strid, I.; Hansson, P.-A. Can carbon footprint serve as an indicator of the environmental impact of meat production? Ecol. Indic. 2013, 24, 573-581. [CrossRef]

108. Scalvedi, M.L.; Saba, A. Exploring local and organic food consumption in a holistic sustainability view. Br. Food J. 2018, 120, 749-762. [CrossRef]

109. Adams, D.C.; Salois, M.J. Local versus organic: A turn in consumer preferences and willingness-to-pay. Renew. Agric. Food Syst. 2010, 25, 331-341. [CrossRef] 
110. Bazzani, C.; Caputo, V.; Nayga, R.M.; Canavari, M. Revisiting consumers' valuation for local versus organic food using a non-hypothetical choice experiment: Does personality matter? Food Qual. Prefer. 2017, 62, 144-154. [CrossRef]

111. Schmitt, E.; Galli, F.; Menozzi, D.; Maye, D.; Touzard, J.-M.; Marescotti, A.; Six, J.; Brunori, G. Comparing the sustainability of local and global food products in Europe. J. Clean. Prod. 2017, 165, 346-359. [CrossRef]

112. Wahlen, S.; Heiskanen, E.; Aalto, K. Endorsing Sustainable Food Consumption: Prospects from Public Catering. J. Consum. Policy 2012, 35, 7-21. [CrossRef]

113. Edwards-Jones, G.; Canals, L.M.; Hounsome, N.; Truninger, M.; Koerber, G.; Hounsome, B.; Cross, P.; York, E.H.; Hospido, A.; Plassmann, K.; et al. Testing the assertion that 'local food is best': The challenges of an evidence-based approach. Trends Food Sci. Technol. 2008, 19, 265-274. [CrossRef]

114. Edwards-Jones, G. Does eating local food reduce the environmental impact of food production and enhance consumer health? Proc. Nutr. Soc. 2010, 69, 582-591. [CrossRef]

115. Coley, D.; Howard, M.; Winter, M. Local food, food miles and carbon emissions: A comparison of farm shop and mass distribution approaches. Food Policy 2009, 34, 150-155. [CrossRef]

116. Granvik, M. The Localization of Food Systems-An Emerging Issue for Swedish Municipal Authorities. Int. Plan. Stud. 2012, 17, 113-124. [CrossRef]

117. Van Der Werf, H.M.G.; Knudsen, M.T.; Cederberg, C. Towards better representation of organic agriculture in life cycle assessment. Nat. Sustain. 2020, 3, 419-425. [CrossRef]

118. Rigby, D.; Cáceres, D. Organic farming and the sustainability of agricultural systems. Agric. Syst. 2001, 68, 21-40. [CrossRef]

119. Garnett, T. What is a Sustainable Healthy Diet? A Discussion Paper; Food Climate Research Network: Oxford, UK, 2014.

120. Garnett, T. Where are the best opportunities for reducing greenhouse gas emissions in the food system (including the food chain)? Food Policy 2011, 36, S23-S32. [CrossRef]

121. Willett, W.; Rockström, J.; Loken, B.; Springmann, M.; Lang, T.; Vermeulen, S.; Garnett, T.; Tilman, D.; DeClerck, F.; Wood, A.; et al. Food in the Anthropocene: The EAT-Lancet Commission on healthy diets from sustainable food systems. Lancet 2019, 393, 447-492. [CrossRef]

122. Del Borghi, A.; Moreschi, L.; Gallo, M. Communication through ecolabels: How discrepancies between the EU PEF and EPD schemes could affect outcome consistency. Int. J. Life Cycle Assess. 2019, 25, 905-920. [CrossRef]

123. Lehmann, A.; Bach, V.; Finkbeiner, M. Product environmental footprint in policy and market decisions: Applicability and impact assessment. Integr. Environ. Assess. Manag. 2015, 11, 417-424. [CrossRef]

124. Laureti, T.; Benedetti, I. Exploring pro-environmental food purchasing behaviour: An empirical analysis of Italian consumers. $J$. Clean. Prod. 2018, 172, 3367-3378. [CrossRef]

125. Del Borghi, A. LCA and communication: Environmental Product Declaration. Int. J. Life Cycle Assess. 2013, 18, 293-295. [CrossRef] 